\title{
Zakończenie likwidacji spółki z o.o. oraz jej sukcesja prawna
}

\section{Completion of the liquidation of the limited liability company and its legal succession}

\author{
mgr Wawrzyniec Żbikowski \\ E-mail: wawrzyniec.zbikowski@amu.edu.pl; nr ORCID: 0000-0001-5987-8537
}

\begin{abstract}
Streszczenie
Celem niniejszego artykułu jest przedstawienie wybranych zagadnień związanych z kończeniem likwidacji spółki z o.o. oraz jej sukcesją prawną. W pierwszej kolejności autor opisuje problematykę samego zwrotu „zakończenie likwidacji”, krytycznie odnosząc się do obecnego stanu prawnego w tej materii. Następnie przedstawiona zostaje możliwość uchylenia likwidacji i powrotu do normalnego funkcjonowania spółki wraz z możliwymi problemami interpretacyjnymi na tym gruncie. W dalszej kolejności zaprezentowana jest kwestia wykreślenia spółki z rejestru, a następnie problematy- ka polikwidacyjnych praw i zobowiązań spółki. Na koniec autor przedstawia postulaty de lege ferenda oraz podsumowanie.
\end{abstract}

Słowa kluczowe: spółka, likwidacja, zakończenie, sukcesja

\section{Summary}

The aim of this study is to present chosen issues related to the completion of the liquidation of the limited liability company and its legal succession. In the first place author describes problems connected to the term "completion of liquidation", critically referring to the current state of legislation in that matter. Further the possibility of liquidation's reversal and resumption of normal functioning of the company is discussed, together with possible interpretation problems regarding that. The next presented matters are deletion from the register and issues of company's post- liquidation rights and obligations. At the end, author presents de lege ferenda postulates and summary.

Key words: company, liquidation, completion, succession

JEL: K22

Str. 9-14

\section{Bibliografia}

Allerhand, M. (1935). Kodeks handlowy. Komentarz. Lwów: „Kodeks” spółka wydawnicza.

Grykiel, J. (2011). Glosa do uchwały SN z 24.01.2007 r., III CZP 143/06, Glosa (2), 17-21.

Kamińska, A. (2017). W: Z. Jara (red.), Kodeks spółek handlowych. Komentarz. Warszawa: C.H. Beck.

Kidyba, A. (2019). Kodeks spótek handlowych. Tom I. Komentarz do art. 1-300. Warszawa: Wolters Kluwer.

Marszałkowska-Krześ, E. (red.). (2018). Kodeks postępowania cywilnego. Komentarz. Legalis/el.

Michalski, M. (2015). W: S. Sołtysiński (red.), System Prawa Prywatnego (t. 17A), Prawo spótek kapitałowych. Warszawa: C.H. Beck.

Naworski, J. (2011). W: T. Siemiątkowski, R. Potrzeszcz (red.), Kodeks spółek handlowych: komentarz (t. 2), Tytuł III - spótki kapitałowe: Dziat I - spótka zograniczona odpowiedzialnością. Warszawa: LexisNexis.

Pabis, R. (2015). W: J. Bieniak, M. Bieniak, G. Nita-Jagielski, K. Oplustil, R. Pabis, A. Rachwał, M. Spyra, G. Suliński, M. Tofel, R. Zawłocki, Kodeks spótek handlowych. Komentarz. Warszawa: C.H. Beck.

Rachwał, A. (2012). W: S. Włodyka (red.), System Prawa Handlowego (t. 2), Prawo spółek handlowych. Warszawa: C.H. Beck.

Słowik, P. (2018). Koszmarny Rejestr Spółek. Na prosty wpis w KRS trzeba czekać nawet pół roku. I jest coraz gorzej. Dziennik Gazeta Prawna (21.02.), https://prawo.gazetaprawna.pl/artykuly/1105836,rejestracja-spolki-w-krs-zator.html (30.04.2019).

Szajkowski, A., Tarska, M. (2014). W: S. Sołtysiński, A. Szajkowski, A. Szumański, J. Szwaja, Kodeks spótek handlowych (t. 2), Spótka z ograniczoną odpowiedzialnością: komentarz do artykułów 151-300. Warszawa: C.H. Beck.

Szczurowski, T. (2015). Nowe kompetencje i obowiązki sądu rejestrowego. Monitor Prawniczy (5), 233-240.

Zamojski, Ł. (2018). Pozycja prawna kuratora ustanowionego dla osoby prawnej na mocy art. 42 k.c. — po zmianach 


\section{Akty prawne}

Rozporządzenie Prezydenta Rzeczypospolitej z 27.06.1934 r. — Kodeks handlowy (Dz. U. nr 57, poz. 502 ze zm.) — k.h. Ustawa z 23.04.1964 r. — Kodeks cywilny (Dz. U. z 2018 r. poz. 1025 ze zm.) - k.c.

Ustawa z 17.11.1964 r. — Kodeks postępowania cywilnego (Dz. U. z 2018 r. poz. 1360 ze zm.) — k.p.c. Ustawa z 20.08.1997 r. o Krajowym Rejestrze Sądowym (Dz. U. z 2018 r. poz. 986 ze zm.) — ustawa o KRS.

Ustawa z 15.09.2000 r. — Kodeks spółek handlowych (Dz. U. z 2019 r. poz. 505 ze zm.) — k.s.h.

Rozporządzenie Ministra Sprawiedliwości z 21.12.2000 r. w sprawie określenia wzorów urzędowych formularzy wniosków o wpis do Krajowego Rejestru Sądowego oraz sposobu i miejsca ich udostępniania (Dz. U. z 2015 r. poz. 724 ze zm.).

\section{Orzeczenia}

Postanowienie SN z 29.06.2001 r., I CZ 73/01, „Orzecznictwo Sądu Najwyższego. Izba Cywilna” 2002/3, poz. 35.

Postanowienie SN z 20.09.2007 r., II CSK 240/07, LEX nr 487505.

Postanowienie SN z 5.12.2003 r., IV CK 256/02, LEX nr 134088.

Uchwała SN z 24.01.2007 r., III CZP 143/06, „Orzecznictwo Sądu Najwyższego. Izba Cywilna” 2007/11, poz. 166.

Postanowienie SN z 18.10.2006 r., II CSK 136/06, Lex nr 398395.

Postanowienie SN z 18.12.1996 r., I CKN 20/96, LEX nr 29098.

Postanowienie SN z 8.01.2002 r., I CKN 752/99, LEX nr 53298.

Postanowienie SN z 5.12.2003 r., IV CK 256/02, LEX nr 134088. 